\title{
Characterization of local geochemical anomalies in soils and stream sediments for improving land-use planning: A case study from Nisa, Portugal
}

\author{
Ana Rita Ferreira1, Sofia Barbosa ${ }^{2}$, José António Almeida ${ }^{2 *}$ \\ ${ }^{1}$ Department of Earth Sciences, Faculdade de Ciências e Tecnologia, Universidade NOVA de Lisboa, Caparica, Portugal, Ferreira, \\ ${ }^{2}$ Department of Earth Sciences and GeoBioTec, Faculdade de Ciências e Tecnologia, Universidade NOVA de Lisboa, Caparica, Portugal
}

\section{A B S TR A C T}

\begin{abstract}
One of the largest and most important near-surface deposits of uranium in Portugal is found in the region of Nisa. Unexploited resources in the Nisa deposit are estimated at about 32 million tonnes of ore. To better understand the processes of natural dispersion of chemicals, such as hydrogravitational erosion and reactive transport, samples of soils and of stream sediments were collected in the vicinity of the Nisa deposit and analysed for chemical signatures of metals (uranium, chromium, molybdenum, niobium, vanadium, and zinc) and semi-metals (arsenic). Stream sediment samples were taken from sites along a 470-m-long stretch of a river bed near the mineralization, with soil samples being collected from riverbanks. Univariate, bivariate, and multivariate statistical analysis as well as GIS mapping tools were used to identify and interpret variations in geochemical concentrations of the different elements and the relationships between them. The analyses allowed local background (reference) values to be established with respect to the geochemical anomaly caused by the mineral deposit. These background values were compared with legislation standards established for the remediation of soils and sediments. Recommendations to be considered in land-use planning with respect to the occurrence of natural geochemical anomalies are presented.
\end{abstract}

Keywords: Land-use planning; Local geochemical anomalies; Soil samples; Stream sediments; Uranium deposit

\section{INTRODUCTION}

Portugal has high geological and geochemical diversity and considerable potential for mineral resources as a result of the occurrence of different metallogenetic provinces (Moura and Velho, 2011). This diversity has generated many natural geochemical anomalies in Portugal. The magnitude of natural geochemical anomalies, as well as their local and regional effects or manifestations, must be taken into account in land-use planning, in environmental impact assessment, and in site remediation projects. The execution of site decontamination projects where the geochemical characteristics of the area are not considered with respect to regulatory values, which are taken as absolute, can result in disproportionate interpretations, biased site evaluations, and overvaluations of the need for and procedures of environmental remediation and recovery (Barbosa, 2014). In addition, mineral occurrence and the geochemical environmental conditions of the site will influence the transport and behaviour of elements and their effectiveness or non-effectiveness as contaminants.

Given the social relevance of geochemical contamination and the factors affecting its assessment, a study area containing a substantial uranium anomaly was selected to exemplify the need to consider the natural geochemical dispersion phenomena of metals and semi-metals in soils and stream sediments. The ore deposit of Monte Claro-Nisa, located in the council of Nisa, Portalegre district (Portugal) was selected for this purpose (Faria and Mesquita, 1962; Portugal, 1971; Alves de Campos, 2002; Neto de Carvalho et al., 2009; Neto de Carvalho and Rodrigues, 2012).

\footnotetext{
*Corresponding author:

José António Almeida, Department of Earth Sciences and GeoBioTec, Faculdade de Ciências e Tecnologia, Universidade NOVA de Lisboa, Campus de Caparica, 2829-616 Caparica, Portugal. E-mail: ja@fct.unl.pt
}

Received: 21 February 2016;

Revised: 29 March 2016;

Accepted: 01 April 2016;

Published Online: 19 April 2016 


\section{THE NATURAL GEOCHEMICAL ANOMALY OF THE URANIUM ORE DEPOSIT OF MONTE CLARO-NISA (PORTUGAL)}

\section{The study area}

The study area covers about 2.2 ha and is located in the Alto Alentejo province, district of Portalegre, near the village of Nisa (Fig. 1, left). The village of Nisa is located to the east of the study area and the village of Monte Claro to the west. The study area extends from the location of the main anomaly to a local rockfill dam. During the 1990s, the area of the geochemical anomaly and surrounding land was investigated using bulk sampling and experimental leaching processing, on which basis the Nisa ore deposit was considered for a pre-feasibility mining study.

\section{Geology of the study area}

Two types of lithology prevail in the municipality of Nisa and surrounding area. In the northern part of the county are found metasedimentary rocks (schists and greywackes) of Ediacaran age. In the southern part is found the Nisa Massif, which is composed mainly of granitic rocks of Hercynian age (Fig. 2). During the Hercynian Orogeny, these batholithic granites were intruded into rocks of sedimentary origin, which led to the formation of the metasediments in a wide belt of contact metamorphism (Ribeiro et al., 1965; Cunha et al., 2009). Also in the northern part of the county, where the study area is located, are found the metasediments of Grupo das Beiras (GB), which form the Schist-Greywacke
Metasedimentary Complex of the Iberian Massif. This geological complex is a $1-\mathrm{km}$-thick flysch-type sequence of schist and greywacke, and is particularly well expressed in the Central Iberian Zone. The sequence has been interpreted as a result of the erosion of the Cadomian Mountain Chain (Solá, 2007). In the Nisa area, the GB comprises a phyllitous-micaceous sequence (composed mainly of sequences of sericite and chlorite, or of sericite, biotite, and chlorite) and quartz-micaceous or micaceous schists, greywackes, meta- greywackes, quartzcalco-silicated schists, phyllites, and black graphitic and phosphatic meta-siltstone (Solá, 2007).

In the southern part of the county is found the Nisa granite batholith, which was intruded at around $300 \mathrm{Ma}$ (Ferreira et al., 1987). Two main facies are distinguished in this batholith: the Gáfete Granite and the Nisa Granite. The Gáfete Granite is a two-mica medium- to fine-grained granite, whereas the larger Nisa Granite body is a coarsegrained, porphyritic monzonitic biotite-muscovite granite containing megacrystals of $\mathrm{K}$-feldspar.

In the study area, the major minerals are quartz, oligoclase and albite-oligoclase, microcline-pertite, micropertite, microcline, biotite, and muscovite, and the accessory minerals are apatite, zircon, andalusite and sillimanite, cordierite, and tourmaline. Secondary minerals include kaolinite, sericite, chlorite, acicular rutile, sphene, pyrite, iron oxides, and hydroxides (Ribeiro et al., 1965; Prazeres, 2011).

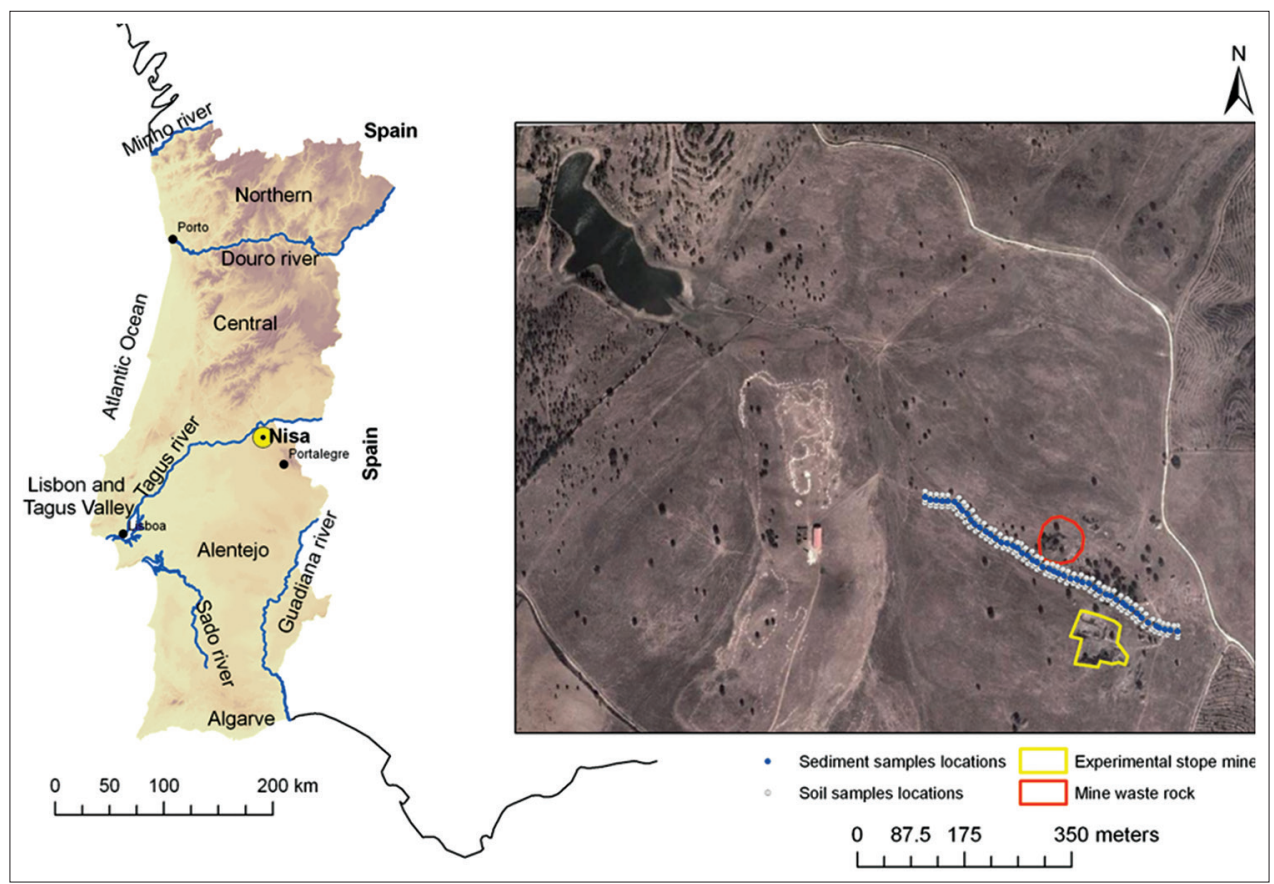

Fig 1. (Left) Map showing the location of the study area of Nisa, Portugal. (Right) Aerial photograph of the study area overlain with soil and sediment sampling locations. 


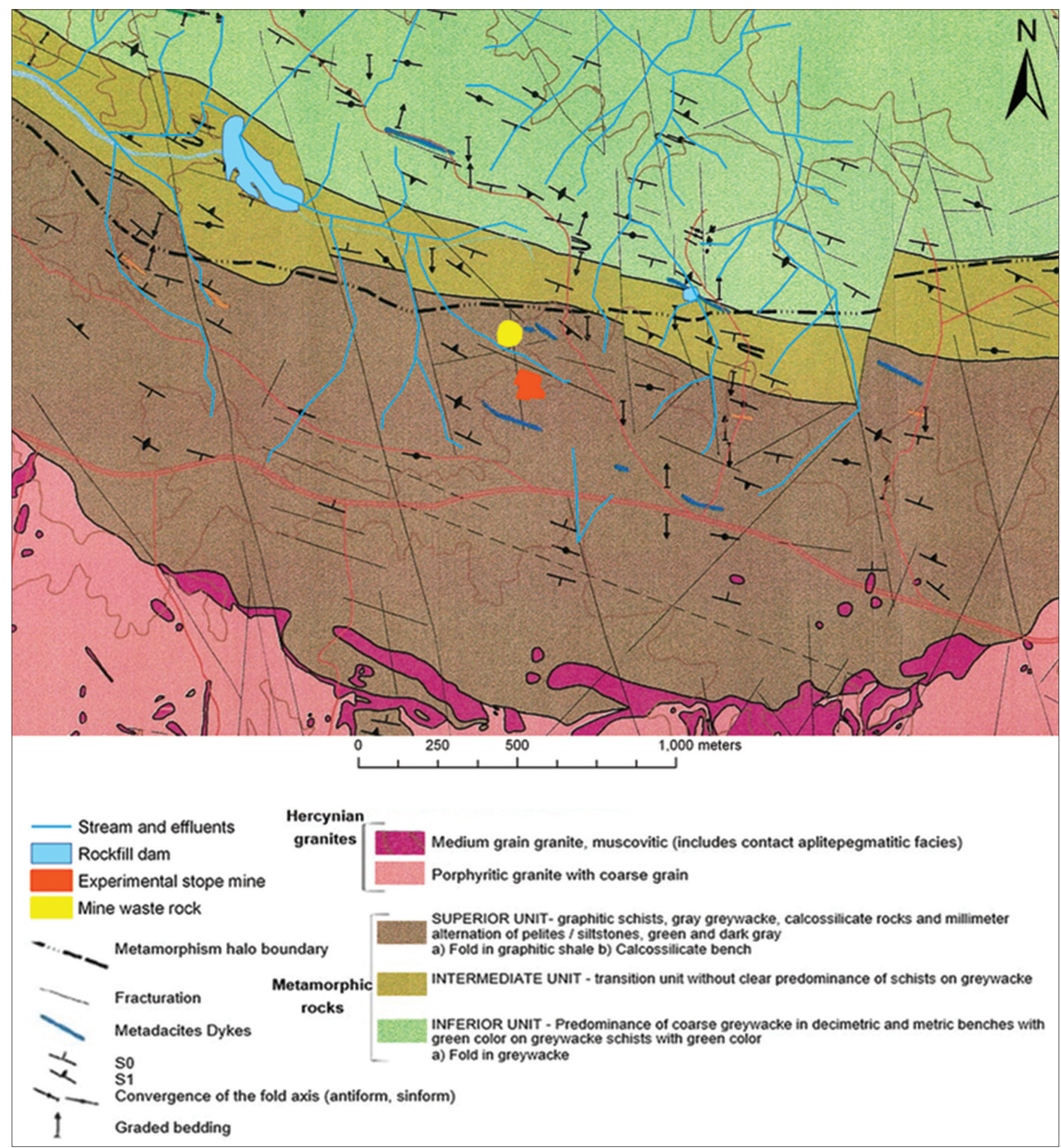

Fig 2. Geological map of the Nisa-Monte Claro region, with the locations of the experimental leaching pilot plant, waste rock, and rockfill dam shown (adapted from Alves dos Campos, 2002).

The Nisa Granite intrusion caused an extensive area of contact metamorphism to occur. This halo of metamorphism is oriented east-west and is about $1.5 \mathrm{~km}$ wide, and cuts across the area of Nisa village. The contact halo is characterised by "cornea" and mottled schist facies. The cornea is composed of black rock with local variations including pelitic zones, quartz-pelitic zones, and calco-silicated porphyroblasts. The most common mineralogical composition of the cornea facies is biotite, cordierite, muscovite, sericite, and quartz, with the accessory minerals being graphite, oxides and hydroxides of iron, feldspar, tourmaline, zircon, and apatite, set in a porphyroblastic matrix of cordierite. The most common mineral assemblage for the mottled schist facies is quartz, 
biotite, muscovite, sericite, and chlorite, with graphite and pyrite being the most abundant accessory minerals (Faria and Mesquita, 1962; Ribeiro et al., 1965).

\section{Mineralogy of the nisa uranium deposit}

The Nisa deposit contains uranium mineralization distributed in crushed, mottled, or impregnated bands along foliation planes in the schist host rock. In exposures of weathered schist, mineralization in foliations is relatively common and is accompanied by limonite impregnation. In less weathered exposures, the edges of the fractures host only small, widely dispersed crystals. Therefore, it would appear that this type of disseminated mineralization is dependent on the occurrence and characteristics of fractures and crushed bands in the schist.

The uranium mineralization is located near the contact with the granite along an axis oriented WNW-ESE, and occurs over a length of about $5 \mathrm{~km}$ and a width varying between 50 and $400 \mathrm{~m}$. The mineralization consists of pyrite, autunite, saleeite, bassetite, phosphuranylite, rare torbernite, and black products of uranium (Faria and Mesquita, 1962; Portugal, 1971; Moura and Velho, 2011).

Explorations of the deposit have shown that the uranium mineralization is confined mainly to the surface and shallow subsurface areas. The richest zone corresponds to the first $25 \mathrm{~m}$, with the concentrations below this depth being drastically lower. At depths of $>50 \mathrm{~m}$, rare anomalous localizations of uranium mineralization have been detected. The mineralization is dependent on fractures characteristics and its occurrences (Faria and Mesquita, 1962; Alves de Campos, 2002). According to Alves de Campos (2002), the estimated deposit volume is 16 million $\mathrm{m}^{3}$ (32 million tonnes) with an average uranium grade of $102 \mathrm{ppm}$.

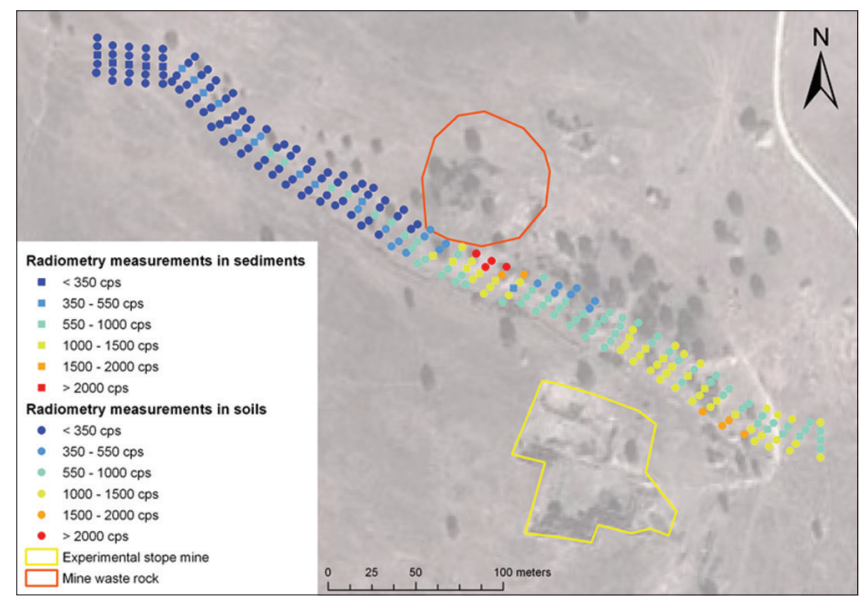

Fig 3. In situ gamma radiation measurements plotted onto an aerial photograph of the study area; regional natural background values are typically less than $350 \mathrm{cps}$.

\section{METHODS}

The initial step of this study was to investigate available information and to obtain topographic maps and satellite photographs, following which GIS georeferencing of the study site was conducted (Fig. 1, right). An area for investigation was selected to make in situ gamma radiation measurements and to collect samples of soils and stream sediments. These sediments were deposited by a river that intersects the area of the local geochemical anomaly, and are used to supply a rockfill dam located downstream in Monte Claro (Rodriguez-Alvarez and Sanchez, 2000; Albanese et al., 2007; United States Army Corps of Engineers, 2007; Kayzar et al., 2014; Neiva et al., 2016). The anomaly is located close to the selected bulk sampling area and to the experimental leaching processing pilot plant that was built for a pre-feasibility mining study of Nisa ore deposit.

Considering the length of the river, which measures about $1050 \mathrm{~m}$ from the main geochemical source to the dam, and also the size of the local anomaly, a stretch of river measuring $470 \mathrm{~m}$ was selected for gamma radiation measurements and sampling. Measurement sites were established along profiles, with profiles spaced at intervals of $10 \mathrm{~m}$ along the selected stretch of river. Along each profile, five in situ gamma radiation measurements were taken, two on each bank of the river and one in the middle of the river bed, with the positions of each measurement site being recorded using GPS (Fig. 1, right). Soil and sediment samples were taken from a random selection of the gamma ray measurement sites, with soils being taken from the banks and sediments being taken from the river bed. A total of 42 sediment or soil samples were collected.

Fig. 3 shows all 240 sites where in situ gamma radiation measurements were made. Of these 240 sites, 23 were used to sample stream sediments and 19 to sample soils. Sediment and soil samples weighed approximately $1 \mathrm{~kg}$ each, and were collected in June 2015 when the river bed was dry, an ideal situation for analysing the fraction that has a higher tendency to be deposited on the bed of the stream and subsequently distributed onto the surrounding surface (floodplain) and into soils surrounding the river.

The gamma radiation measurements were performed both in situ and subsequently in the laboratory using a calibrated portable scintillometer (SPP2 from Saphymo-PHY) with an $\mathrm{NaI}$ detector. Values are reported in counts per second (cps). This instrumentation allows both natural and artificial radionuclides to be detected (Siegbahn, 1965).

In the laboratory, the soil and sediment samples were homogenized, disaggregated, and quartered, following the 
usual procedures for preparation of samples (Kayzar et al., 2014). For determining metal and semi-metal elemental concentrations, an X-ray fluorescence spectrometer (Thermo Scientific Niton XL3p X-ray) was used, with measurements being made in $\mathrm{ppm}$. In fluorescence spectrometry, each element has a distinctive energy released, allowing different elements to be identified and their concentrations measured (Beckhoff, 2006).

To analyse possible patterns between grain size and chemistry, the chemical concentrations of samples were measured for different particle size classes. These classes

Table 1: Summary of basic statistics: average, median, variance, standard deviation, coefficient of variation, interquartile range, maximum, minimum, and skewness for the seven studied elements

\begin{tabular}{|c|c|c|c|c|c|c|c|}
\hline Basic statistics & $\mathbf{U}$ & As & $\mathrm{Cr}$ & Mo & $\mathrm{Nb}$ & V & $\mathrm{Zn}$ \\
\hline \multicolumn{8}{|l|}{ Central } \\
\hline Average & 172.3 & 44.4 & 86.9 & 17.5 & 20.5 & 102.0 & 102.7 \\
\hline \multicolumn{8}{|l|}{ Position } \\
\hline Median & 167.9 & 41.3 & 84.4 & 17.4 & 19.7 & 98.3 & 102.0 \\
\hline \multicolumn{8}{|l|}{ Dispersion } \\
\hline$\sigma^{2}$ & 13584.01 & 161.72 & 253.30 & 110.33 & 61.98 & 469.06 & 462.62 \\
\hline$\sigma$ & 116.55 & 12.72 & 15.92 & 10.50 & 7.87 & 21.66 & 21.51 \\
\hline $\mathrm{Cv}$ & 0.7 & 0.3 & 0.2 & 0.6 & 0.4 & 0.2 & 0.2 \\
\hline IQR & 148.4 & 14.8 & 19.0 & 14.0 & 11.0 & 31.6 & 13.4 \\
\hline Maximum & 643.4 & 80.3 & 132.7 & 61.2 & 52.1 & 168.2 & 203.2 \\
\hline Minimum & 21.8 & 22.0 & 48.1 & 5.5 & 9.7 & 70.3 & 71.6 \\
\hline \multicolumn{8}{|l|}{ Asymmetry } \\
\hline Skewness & 1.626 & 0.950 & 0.505 & 1.786 & 1.622 & 0.802 & 2.518 \\
\hline
\end{tabular}

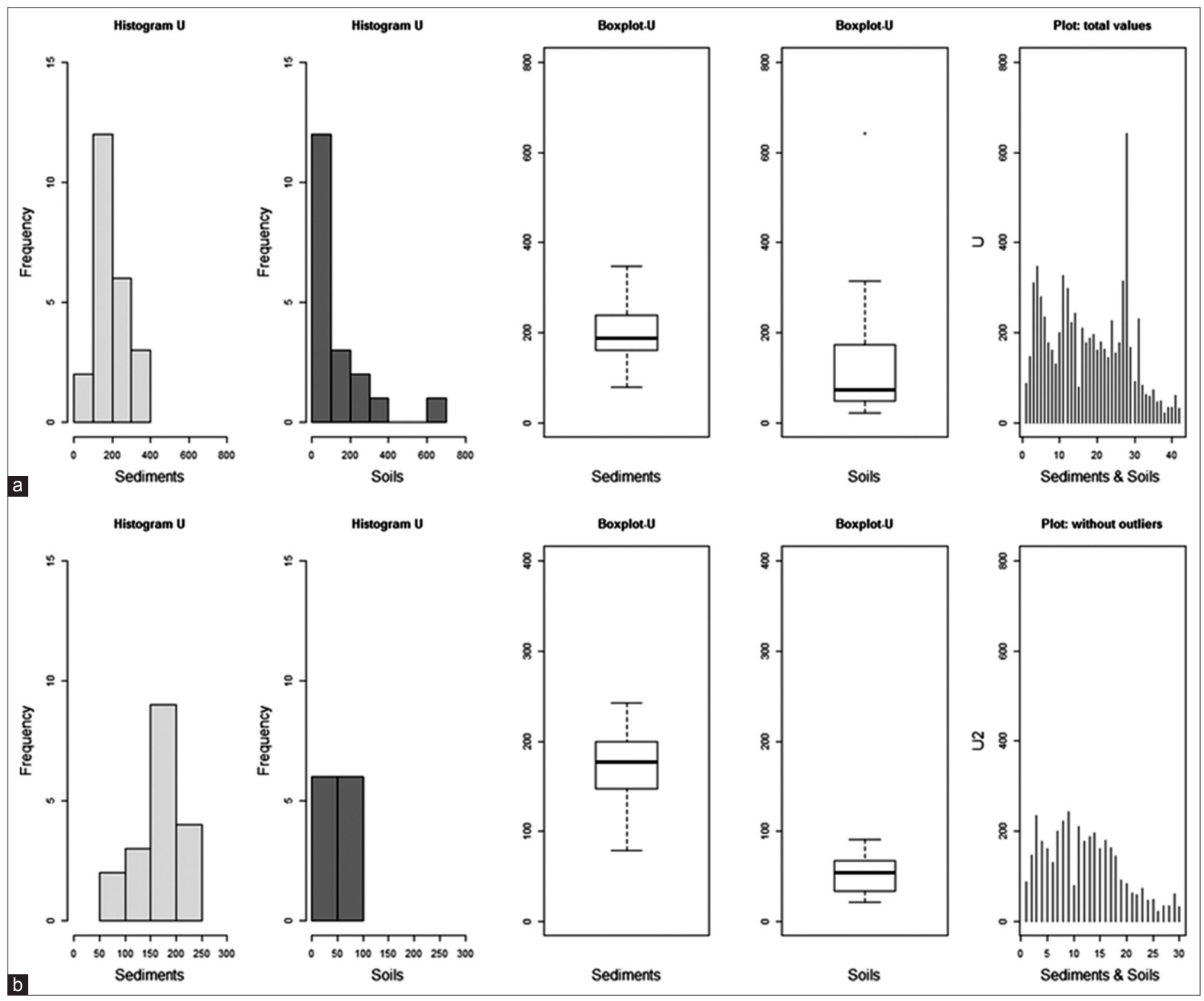

Fig 4. Chemical concentrations of uranium in sediments and soils (a) with and (b) without outlier values, showing the effects of outliers on the asymmetry, central position, and dispersion of observed concentration values in sediments and soils. 


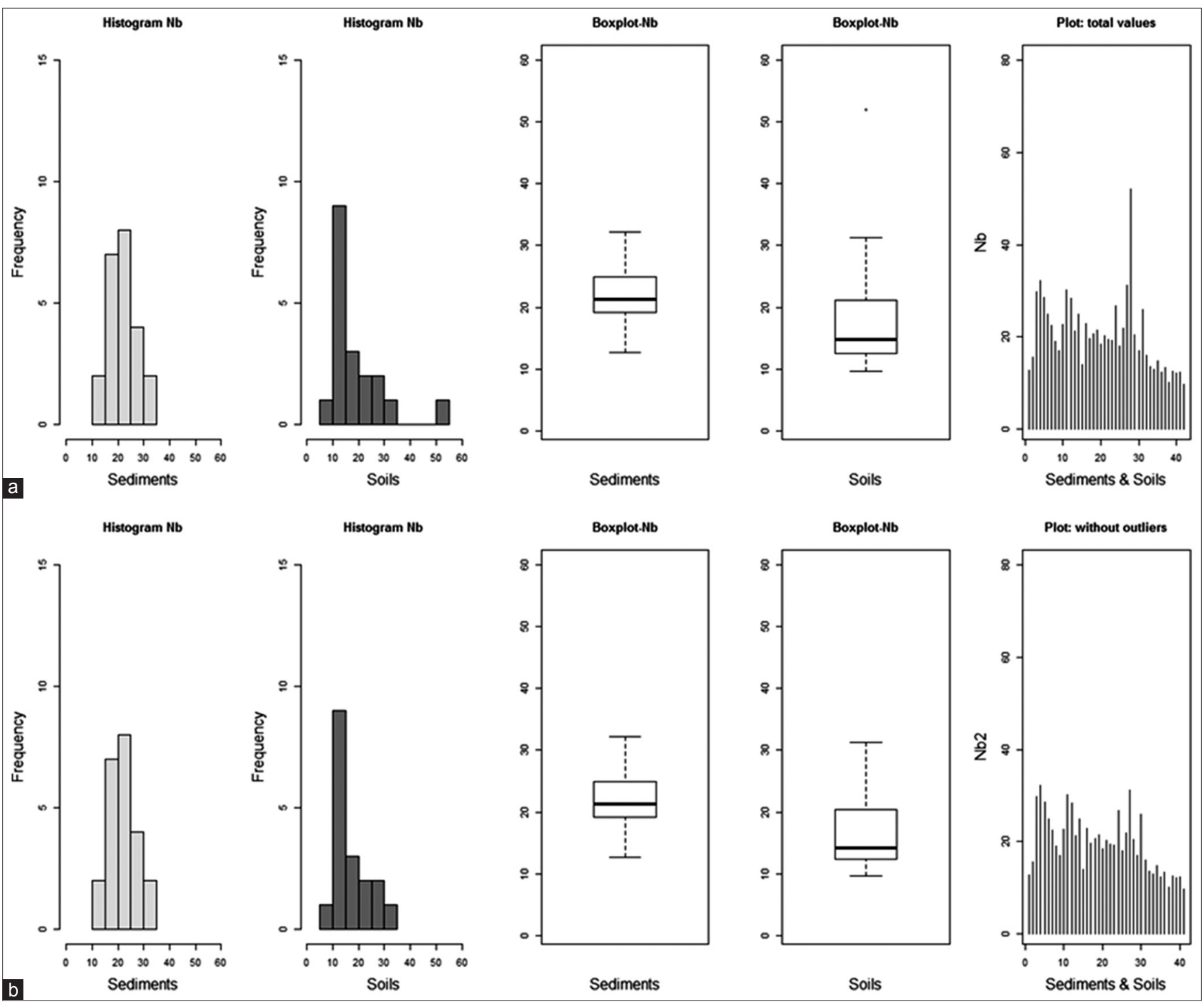

Fig 5. Chemical concentrations of niobium in sediments and soils (a) with and (b) without outlier values, showing the effects of outliers on the asymmetry, central position, and dispersion of observed concentration values in both sediments and soils.

were numbered from 1 to 7 and were defined in terms of the following size fractions: $1=<63 \mu \mathrm{m}, 2=63-125 \mu \mathrm{m}$, $3=125-250 \mu \mathrm{m}, 4=250-500 \mu \mathrm{m}, 5=500 \mu \mathrm{m}$ to $1 \mathrm{~mm}$, $6=1-2 \mathrm{~mm}$, and $7=2-4 \mathrm{~mm}$. To ensure representative results, three measurements for each grain size class for each sample were made. An analysis of the main statistical parameters for central position and dispersion was made to determine whether the mean of the three measurements made for each class for each sample was significant. The mean of the three measurements was taken as the value of elemental concentration considered for each sample and was used for further data analysis and interpretation.

The elements U (uranium), As (arsenic), Cr (chromium), Mo (molybdenum), $\mathrm{Nb}$ (niobium), $\mathrm{V}$ (vanadium), and $\mathrm{Z}$ (zinc) were measured and analysed on account of their higher concentrations, both with respect to typical Clarke values and to normal values found in soils and sediments derived from similar lithologies to those in the present study but in the absence of geochemical anomalies. Univariate, bivariate, and multivariate exploratory data analysis was performed to explore patterns in the measured elemental concentrations (Isaaks and Srivastava, 1989; Salgueiro et al., 2007; Alexakis, 2008; Cheng et al., 2010; Sakan et al., 2011; Charifo et al., 2015). Maps showing measured concentrations of elements along the river were also constructed using GIS tools (Soares et al., 1993; Albanese et al., 2007; Alexakis, 2008; Cheng et al., 2011; Cabral-Pinto et al., 2014; Guimarães et al., 2014; Roxo et al., 2016).

\section{RESULTS AND DISCUSSION}

Fig. 3 shows the spatial distribution of in situ gamma radiation values measured in both stream sediments and 
soils. Natural regional background values of gamma radiation in the Nisa region are typically less than $350 \mathrm{cps}$. The mean gamma radiation value obtained was 823 cps from the in situ measurements and $95 \mathrm{cps}$ from the laboratory measurements (about 10 times less). The measurements made in situ show contributions of natural surrounding environment radioactivity because they were made in an area of natural uranium mineralization where the local background value is considerably higher. In the laboratory, the background does not contain this anomalous radiation value, and therefore the radiometry shows substantially lower values. It is relevant to note that with increasing distance from the mineralization, that is, in downstream areas of the river, there is a closer correspondence of the in situ values with the regional background and the laboratory values. This is because of the reduced background radiation with increasing distance from the local anomaly.

\section{Univariate statistics}

Basic statistical parameters of central position, dispersion, and asymmetry of elemental concentrations in the samples were computed (Table 1). Different asymmetry behaviours and outliers were also identified for elemental concentration data in both sediments and soils (Figs. 4 and 5).
In the context of this study, it is important to note that a less asymmetrical distribution of elemental concentration reflects the absence or low prevalence of outliers and therefore a data pattern that is more regular. In a situation where natural geochemical anomalies in soils and sediments are being analysed, and without the existence of any other contaminating effects, a recognized approach is to eliminate the significant outliers that lie outside the main range of concentration values. The mean and median values will therefore be nearer to each other, reflecting a distribution that is closer to a normal distribution (Figs. 4 and 5). The coefficient of skewness and data variance will also be lower. Consideration of the central position statistics without significant outliers can be used to establish reference values for a particular dataset of soils and sediments (Albanese et al., 2007). These reference values can then be effectively applied to soils and sediments in the presence of natural geochemical anomalies, and comparisons made with guideline or standard values set by regulation. With particular respect to the present study, the identification of samples showing larger asymmetries in elemental concentration data indicated that one sample included an ore specimen. The ore sample elemental data were therefore removed from further bivariate and multivariate analysis because these data were unrepresentative of the sediments and soils.

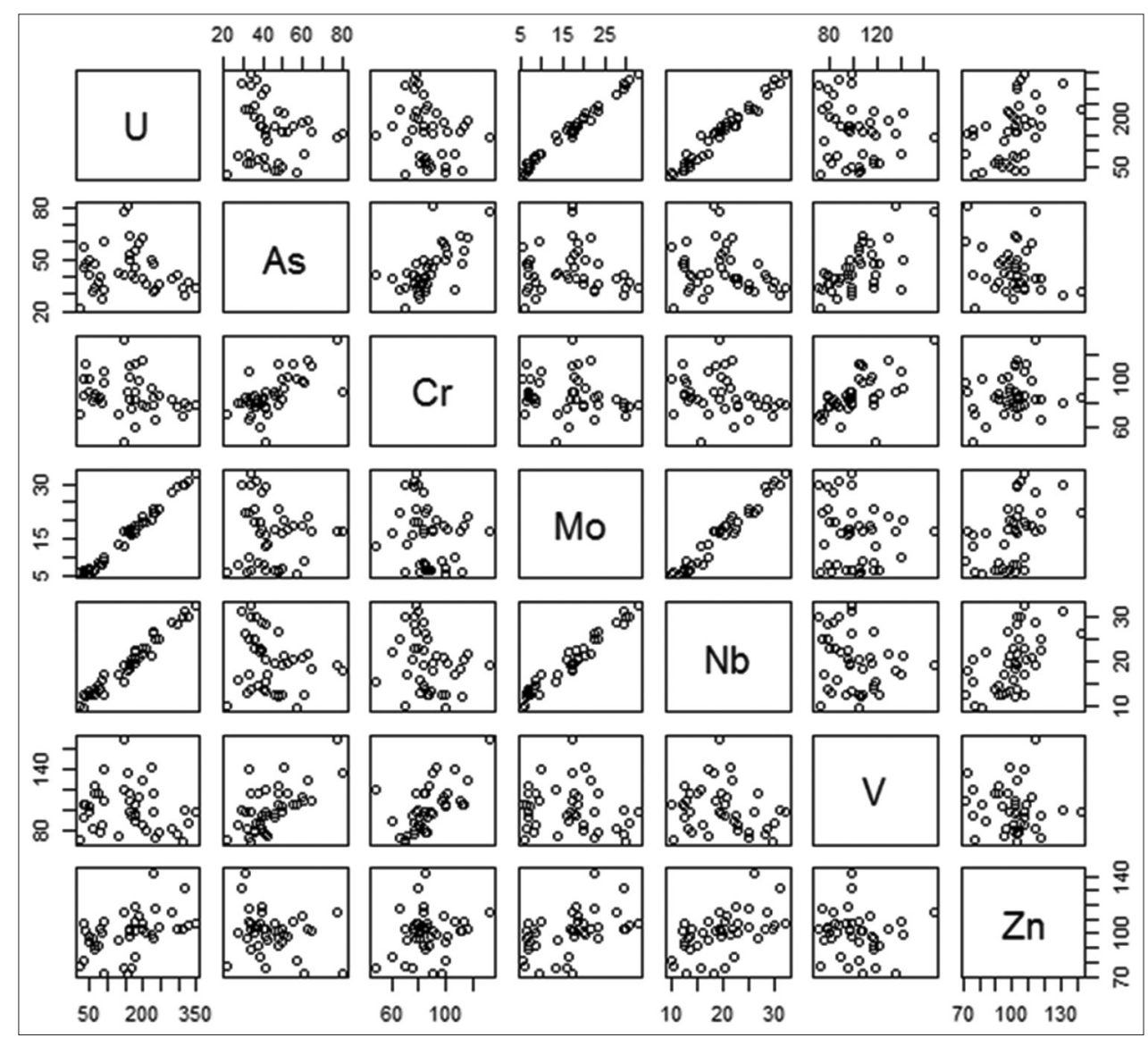

Fig 6. Matrix of scatter diagrams for $\mathrm{U}, \mathrm{As}, \mathrm{Cr}, \mathrm{Mo}, \mathrm{Nb}, \mathrm{V}$ and $\mathrm{Zn}$, after removal of the ore sample outlier. 
Of the seven elements selected for study, $\mathrm{U}$ has the highest concentrations, of up to $643.44 \mathrm{ppm}$ and an average of $172.3 \mathrm{ppm}$. The standard deviation is also the highest, confirming a greater dispersion of values around the mean compared with the other elements. The elements with lower concentrations are $\mathrm{Mo}$ and $\mathrm{Nb}$, with maximums of $61.2 \mathrm{ppm}$ and $52.1 \mathrm{ppm}$, respectively, and means of $17.5 \mathrm{ppm}$ and $20.5 \mathrm{ppm}$, respectively. The deviation coefficient for all elements is less than 1, which means that the dispersion of the data is relatively low. The highest deviation coefficient value occurs in $\mathrm{U}(0.7)$ and the lowest in $\mathrm{Cr}, \mathrm{V}$, and $\mathrm{Zn}(0.2)$.

\section{Bivariate statistics}

A matrix of scatter diagrams for the seven different elements (Fig. 6) shows that the element pairs U/Mo, $\mathrm{U} / \mathrm{Nb}$, and $\mathrm{Mo} / \mathrm{Nb}$ exhibit very high correlations. The element pairs As/Cr and V/Cr exhibit moderate correlations and As/V presents a low correlation. Zn shows a particular behaviour, having no significant correlation with any other element.
According with Fig. 6, statistical similarities between two main groups may be considered: I) U-Mo-Nb and II) As-Cr-V. The selected elements, $\mathrm{U}, \mathrm{Mb}, \mathrm{Nb}, \mathrm{As}, \mathrm{Cr}$ and $\mathrm{V}$ may be explained by different aspects related with the Nisa uranium ore deposit genesis. In fact, the diversity of elements, both of mafic and sedimentary origin $(\mathrm{Cr}, \mathrm{V}$ and $\mathrm{Mo}$ ) or felsic ( $\mathrm{U}$ and $\mathrm{Nb})$, is justified by the occurrence of a halo resulting from contact metamorphism between Hercynian Granites and local original sedimentary formations that results in Schist-Greywacke Metasediments Complex.

The $\mathrm{Cr}$ and $\mathrm{Zn}$ elements have no direct connection with uranium deposits. However, along with the elements $\mathrm{Mo}, \mathrm{Nb}$ and $\mathrm{V}$, corresponds to elements of very typical sedimentary rocks. It is therefore justified its abundance as are characteristic elements of the regional massif, typical of its geochemical signature.

The As occurs in this area in abnormal concentrations. This is a natural pattern and explains why this element

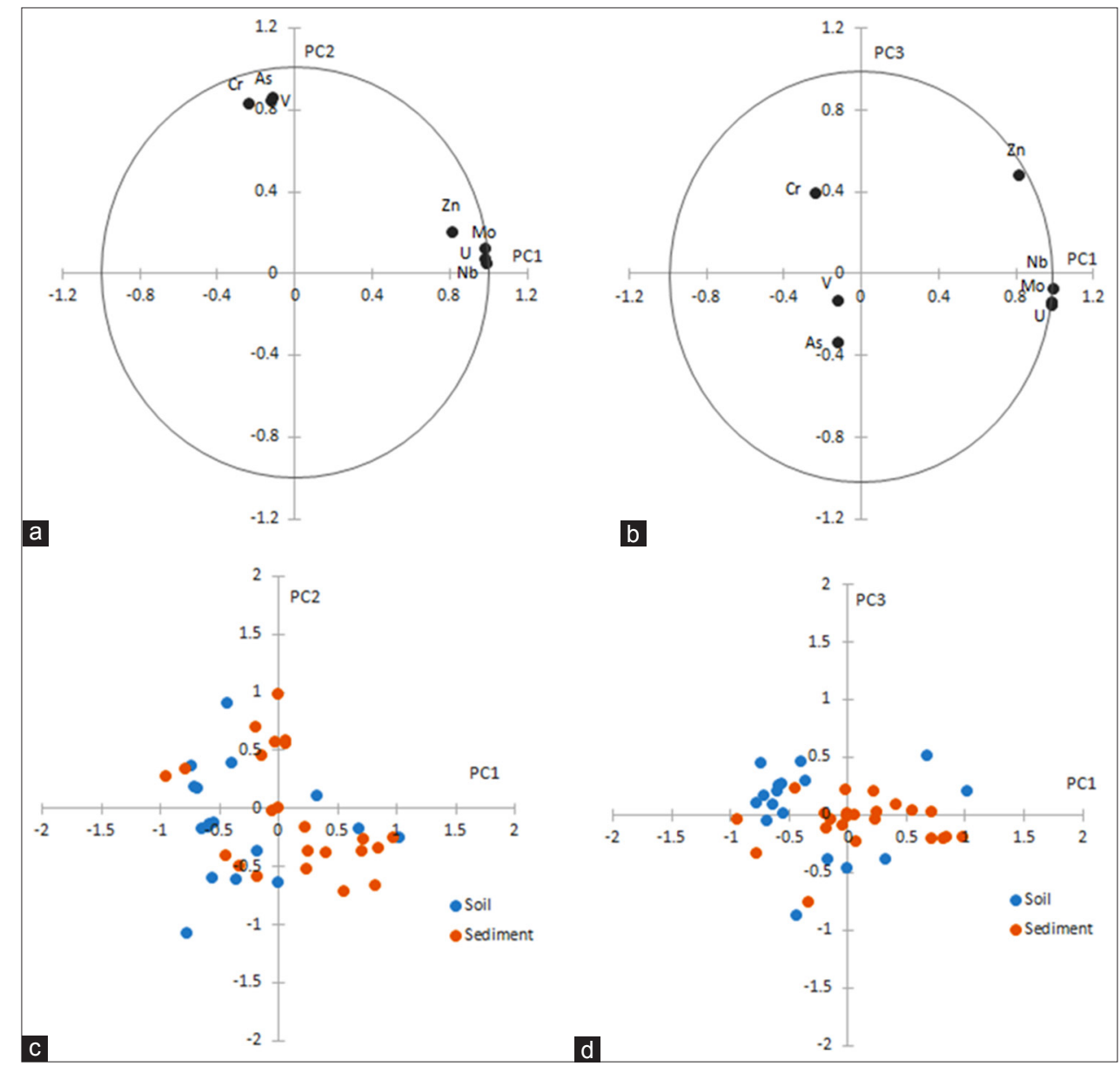

Fig 7. PCA results: a) Projection of the loadings of the variables in the $1^{\text {st }}$ and $2^{\text {nd }}$ factorial plane; b) projection of the loadings of the variables in the $1^{\text {st }}$ and $3^{\text {rd }}$ factorial plane; c) projection of the observations in the $1^{\text {st }}$ and $2^{\text {rd }}$ factorial plane, points are coloured by soil and sediments; d) projection of the observations in the $1^{\text {st }}$ and $3^{\text {rd }}$ factorial plane, points are coloured by soil and sediments. 


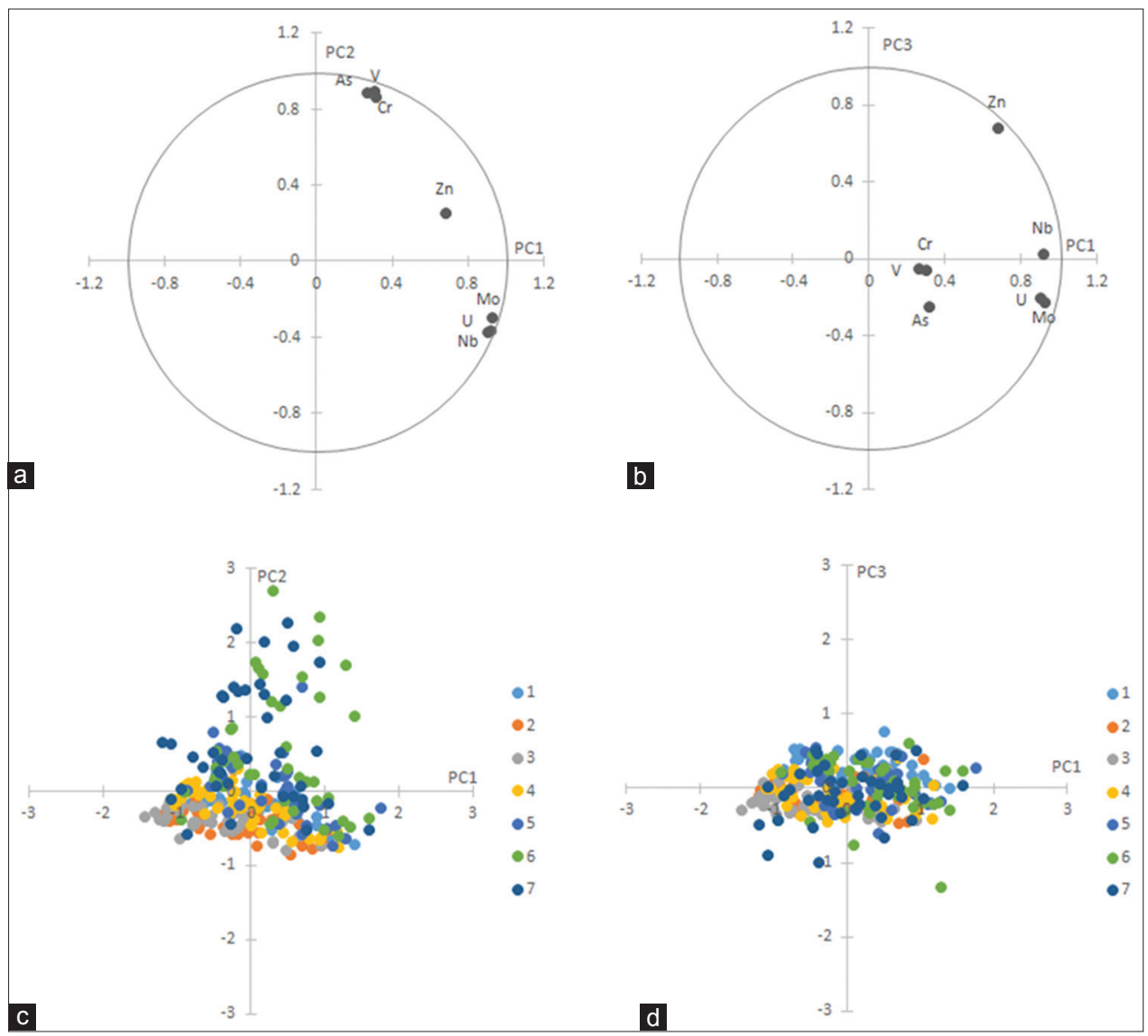

Fig 8. PCA results, concentrations are separated by classes of particle size: a) Projection of the loadings of the variables in the $1^{\text {st }}$ and $2^{\text {nd }}$ factorial plane; b) projection of the loadings of the variables in the $1^{\text {st }}$ and $3^{\text {rd }}$ factorial plane; c) projection of the observations in the $1^{\text {st }}$ and $2^{\text {rd }}$ factorial plane, points are coloured by size class; d) projection of the observations in the $1^{\text {st }}$ and $3^{\text {rd }}$ factorial plane, points are coloured by size class.

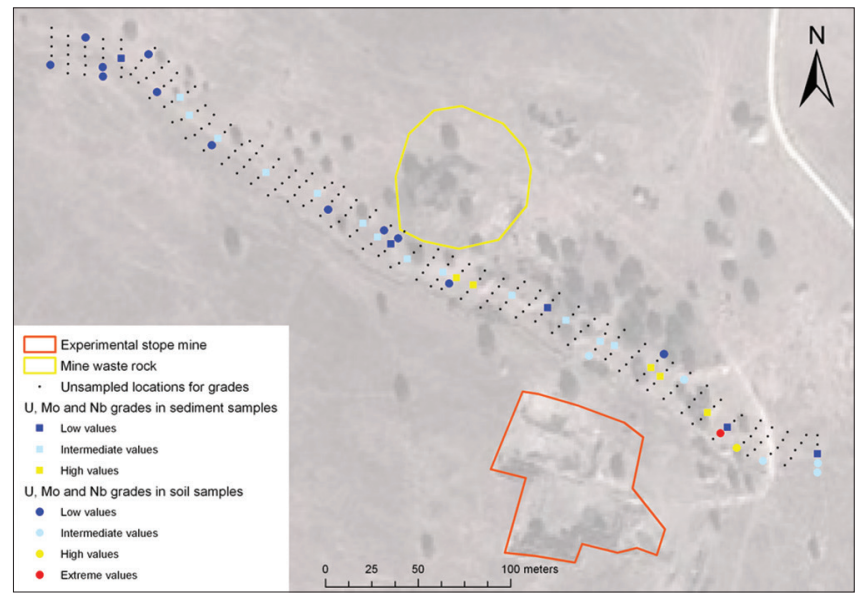

Fig 9. Distribution of the chemical concentrations (by value class) of uranium, niobium, and molybdenum in soil and sediment samples.

is used as a pathfinder in uranium exploration. As has various hosts minerals, including feldspar and pyrite, which are present in the paragenesis of Nisa ore deposit. The high levels of this element are a natural consequence geological history and mineralization to that the area was subjected. As is associated with uranium deposits of $\mathrm{U}-(\mathrm{Co}) \mathrm{V}-\mathrm{As}-\mathrm{Mo}$ type, where the influence of formation

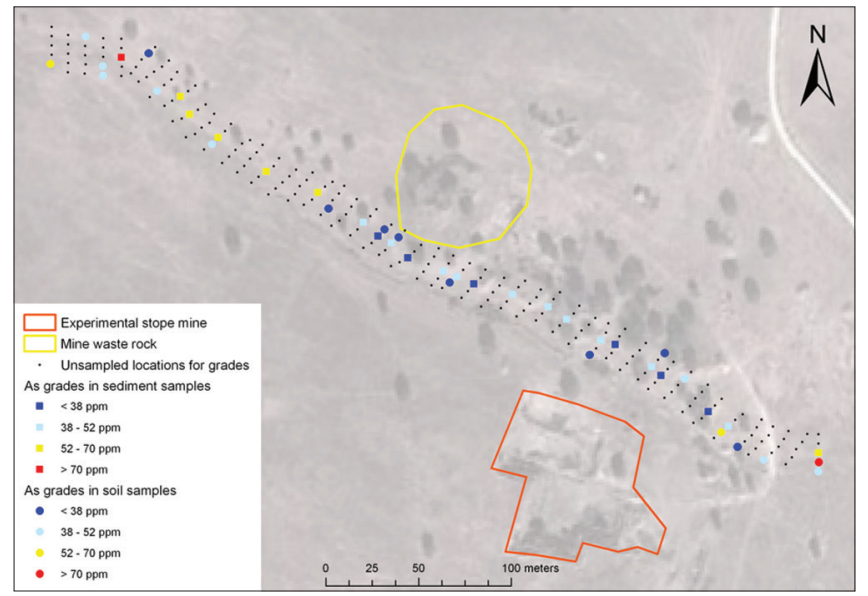

Fig 10. Distribution of the concentration of arsenic in soil and sediment samples.

of sedimentary origin combined with hydrothermal activity can be assumed, and this is the case of the Nisa ore deposit.

With univariate and bivariate statistical analysis it was possible to identify the most representatives elements present in higher concentration in soils and sediments 


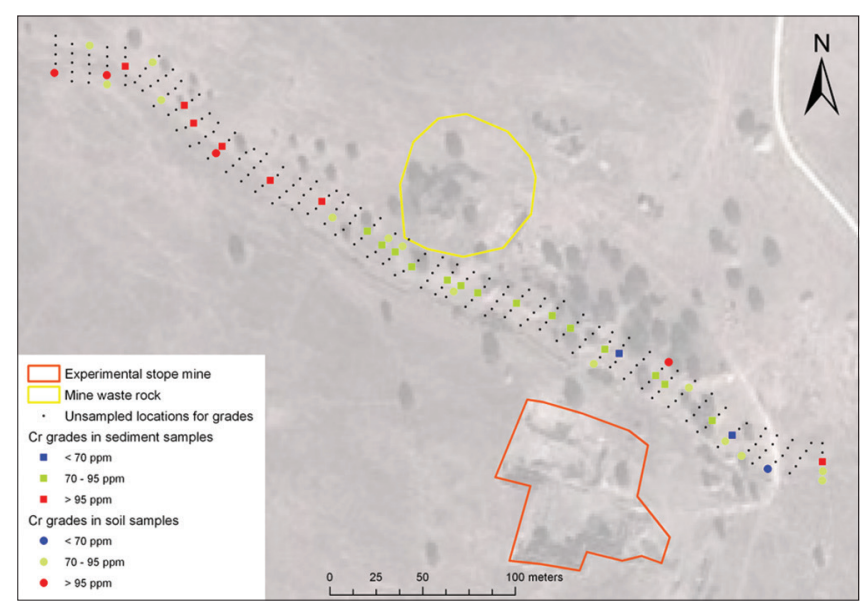

Fig 11. Distribution of the concentration of chromium in soil and sediment samples.

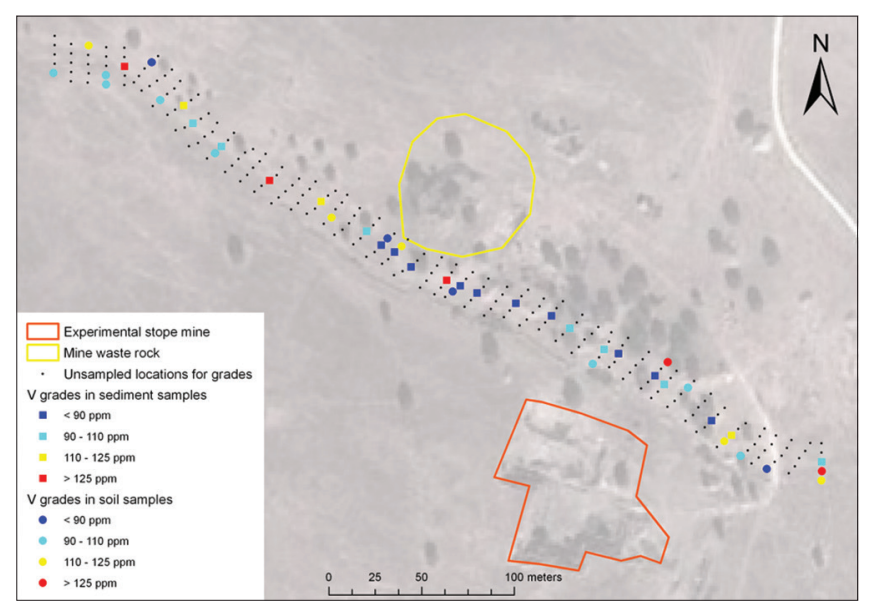

Fig 12. Distribution of the concentration of vanadium in soil and sediment samples.

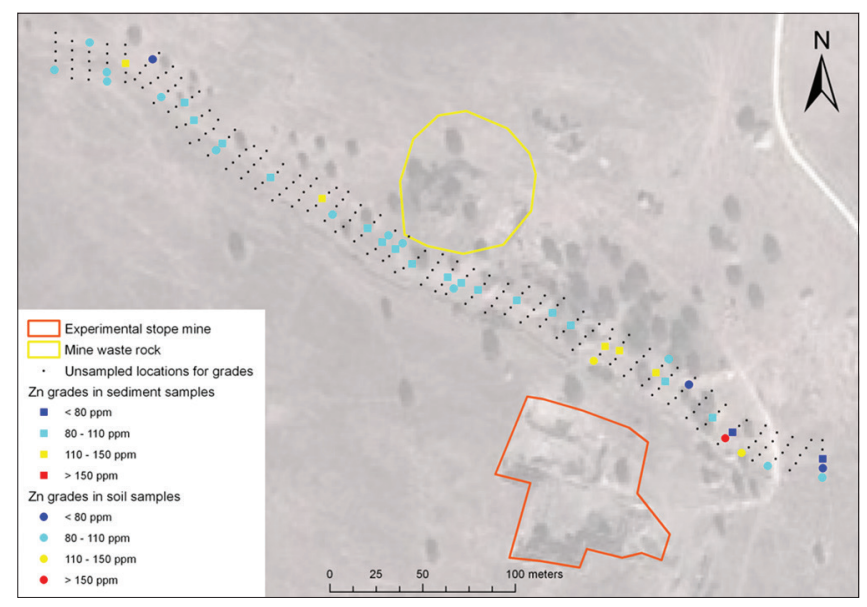

Fig 13. Distribution of the concentration of zinc in soil and sediment samples.

of the studied geochemical anomaly area. The find intercorrelations between these elements maybe explain by ore deposit paragenesis and mineralization history.

\section{Principal component analysis (PCA)}

Principal Component Analysis (PCA) technique was performed with the aim of confirming and reinforcing the previous correlations detected between the different elements (Fig. 7) and also with the sense of identifying possible patterns and variations between the seven selected elements (U, As, Cr, Mo, Nb, V and $\mathrm{Zn}$ ) and grain size class (Fig. 8).

With PCA it was possible to confirm U-Mo-Nb and As$\mathrm{Cr}-\mathrm{V}$ association groups and that the $\mathrm{Zn}$ has a particular behaviour, not being highly correlated with any of the other elements. This behaviour is well patent by its relations with factorial axis 3 (Fig. 7b). Group I, composed by the elements $\mathrm{U}, \mathrm{Mo}$ and $\mathrm{Nb}$, is well correlated with the axis 1 and the group II formed by the elements As, Cr and V is well explain by axis 2 (Fig. 7a).

The projection of the observations in the $1^{\text {st }}$ and $2^{\text {nd }}$ factorial plan considering classification on "soils" and "sediments" reveals that concentrations of both groups are tendentiously higher in sediments than in soils (Fig. 7c and Fig. $7 \mathrm{~d}$ ). In factorial axis 3 where the $\mathrm{Zn}$ component is well correlated, it is also found that the sediments have a better correlation, indicating that their concentrations in $\mathrm{Zn}$ element will be higher when compared to concentrations in soil.

For the analysis of possible relations between the seven selected elements (U, As, Cr, Mo, Nb, V and $\mathrm{Zn}$ ) and grain size class, a PCA with the separation of observations regarding this characteristic was performed. Two main aspects were identified (Fig. 8). The first is related with the existence of the two main groups already identified. Also, the element $\mathrm{Zn}$, with an explanation distributed among the axles 1 and 3 , presents a relative position away from the remaining variables.

By analysing the projection of the observations in the $1^{\text {st }}$ and $2^{\text {nd }}$ factorial plan of PCA (Fig. 8c and Fig. 8d) it is observed that the As, Cr, and V (Group II) exhibit higher levels for higher grain size classes, 6 and 7. Fractions 6 and 7 are well correlated with the axis 2 such as the group II in Fig. 8a. In the other elements does not occur segregation by grain size class.

\section{Spatial analysis}

Using GIS tools, the spatial distribution of elemental concentrations in samples was examined (Figs. 9-13). Categorization of elemental concentrations values in "Low", "Intermediate", "High" and "Extreme" classes were established considering statistical results of each element and coherence archived by each class in its spatial pattern distribution (see Table 2). 
$\mathrm{U}, \mathrm{Nb}$, and Mo exhibit very similar behaviour, and for that reason it was possible to represent them in the same map (Table 2 and Fig. 9). Elemental concentrations upstream of the experimental open pit are low or intermediate, and downstream of the experimental open pit are more erratic, with high, intermediate, and low values being observed in both soils and sediments. A unique and very high concentration of those elements was observed from the sample taken from a pile of ore. As mentioned above, the measured elemental values of that sample were significant outliers and were not included in the statistical analysis.

The elements of group II (As, Cr, and V) show very similar behaviour but one that is distinct from that displayed by the elements of group I. Group II elemental concentrations are higher in the upstream portions of the river bed, including upstream of the experimental open pit. This is probably due to local environmental oxidising conditions and the consequent mobility that some of these elements present, such as the case of As. These elements are also characterized by higher concentrations in coarser grain size classes. This may be cause of the prevalence of these elements in their characteristic oxidizing stages, namely, $\mathrm{As}^{+3}, \mathrm{Cr}^{+6}$, and $\mathrm{V}^{+5}$. As, $\mathrm{Cr}$, and $\mathrm{V}$ tend to (re)precipitate in nature in oxidizing conditions, that is, they are leached, transported, and (re)precipitated in the form of secondary minerals. Effects related to adsorption/precipitation may occur, particularly on the surfaces of coarser grains. The behaviour of $\mathrm{Zn}$ is different from that of the other elements, with concentrations of this element exhibiting low variation along the river.

Table 2: Classes of chemical concentrations of uranium, niobium, and molybdenum in soil and sediment samples

\begin{tabular}{lccc}
\hline $\begin{array}{l}\text { Classes of chemical } \\
\text { concentrations }\end{array}$ & $\mathrm{U}(\mathrm{ppm})$ & $\mathrm{Mo}(\mathrm{ppm})$ & $\mathrm{Nb}(\mathrm{ppm})$ \\
\hline Low & 150 & 15 & 18 \\
Intermediate & $150-250$ & $15-25$ & $18-28$ \\
High & $250-350$ & $25-50$ & $28-40$ \\
Very high & $>350$ & $>50$ & $>40$ \\
\hline
\end{tabular}

COMPARISON OF NATURAL BACKGROUND METAL AND SEMI-METAL ELEMENTAL CONCENTRATIONS WITH STANDARD GUIDELINE SAFETY VALUES

The statistical analysis reported above was able to define the baseline or typical background values (Albanese et al., 2007) for the seven studied elements (U, As, Cr, Mo, Nb, $\mathrm{V}$, and $\mathrm{Zn}$ ) as measured in soils and stream sediments with respect to the existence of the uranium geochemical anomaly in the study area.

To emphasise the relevance of considering the natural geological and geochemical context when establishing safety reference values for metals in soils and sediments, the results obtained in the present study were compared to the values obtained from two different regulatory standards (Dutch Legislation VROM, 2000; Ministry of the Environment, 2011). Safety reference values presented in these guidelines were compared to the mean values obtained from the analysed soil and stream sediment samples.

The results presented in Table 3 are useful in providing insights into how concentrations of metals and semimetals may vary as well as how they may show elevated values compared with safety reference values for soils and sediments, even when considering different degrees of sensitivity and different land-uses and occupational activities. These variations are more relevant for those elements typically included in the geochemical signature of ore deposits and anomalies that are naturally present in soils and sediments. This is the case, for example, of the uranium and arsenic levels detected in the soil and sediment samples that were collected in the Nisa area in the vicinity of the main anomaly. It is also important that different local and regional background values for metals and semi-metals in soils and sediments are considered with respect to distance from the main area of mineralization.

Table 3: Local background values of $\mathrm{U}, \mathrm{As}, \mathrm{Cr}, \mathrm{Mo}, \mathrm{Nb}, \mathrm{V}$, and $\mathrm{Zn}$ for soils and sediments in the vicinity of the Nisa uranium ore deposit compared with the safety reference threshold values given in Ontario guidelines and Dutch standards

\begin{tabular}{|c|c|c|c|c|c|c|c|}
\hline \multirow[t]{3}{*}{ Element } & \multicolumn{2}{|c|}{$\begin{array}{l}\text { Background values in the } \\
\text { study area }\end{array}$} & \multicolumn{3}{|c|}{$\begin{array}{c}\text { Ontario guidelines } 2011 \\
\text { (Table 1: Full Depth Background Site Condition } \\
\text { Standards) }\end{array}$} & \multirow{2}{*}{\multicolumn{2}{|c|}{$\begin{array}{l}\text { Dutch standard values } 2000 \\
\text { Soil and Sediments (ppm) }\end{array}$}} \\
\hline & Soil (ppm) & Sediments (ppm) & Soil (ppm & & Sediments & & \\
\hline & \multicolumn{2}{|c|}{$\begin{array}{c}\text { Average values without } \\
\text { outliers }\end{array}$} & $\begin{array}{l}\text { Residential, industrial, } \\
\text { or commercial use }\end{array}$ & $\begin{array}{l}\text { Agricultural } \\
\text { use }\end{array}$ & (ppm) & $\begin{array}{c}\text { All } \\
\text { uses }\end{array}$ & Intervention value \\
\hline As & 44.15 & 42.75 & 18 & 11 & 6 & 29 & 55 \\
\hline U & 160.79 & 185.92 & 2.5 & 1.9 & - & - & - \\
\hline Mo & 16.45 & 18.61 & 2 & 2 & - & 0.5 & 200 \\
\hline V & 101.54 & 100.13 & 86 & 86 & - & 42 & 250 \\
\hline $\mathrm{Cr}$ & 87.00 & 85.98 & 70 & 67 & 26 & 100 & 380 \\
\hline $\mathrm{Nb}$ & 19.71 & 21.35 & - & - & - & - & - \\
\hline $\mathrm{Zn}$ & 100.27 & 104.51 & 290 & 290 & 120 & 140 & 720 \\
\hline
\end{tabular}


Several metals and semi-metals can occur anomalously in soils and stream sediments in concentrations above the acceptable limits as defined in toxicity standards, regulations, and guidelines. Such anomalies are due to processes that naturally occur in geological systems. In establishing safety reference elemental concentrations in soils and sediments, not only mean concentrations of such elements but also measures of their bioavailability and biotoxicity are key indicators (Takac et al., 2009; McGrath and Semple, 2010). For an initial analysis of this, it is advisable to evaluate metal/semi-metal dispersion and bioavailability according to the environmental factors that influence the transport and dynamics of elements within different mediums and between different mediums (for example, water-soil-plant systems). Physical and reactive transport capacity in mediums depends on various environmental factors (Zheleznyaket al., 1997; Rodriguez-Alvarez et al., 2000; IAEA, 2001; Neiva et al., 2016). For these reasons, there is a high probability that proportions of metals and semi-metals in an area are not "geo-available" or "bio-available", and therefore only a proportion of each measured concentration is available in a contamination sense.

The identification and characterization of natural geochemical anomalies should not be neglected in landuse planning. Consideration of geochemical anomalies must always be taken into account when performing impact assessment, risk assessment, remediation, or environmental rehabilitation projects. However, safety reference guideline or standard values are established with respect to the possible effects on human health, and these values may be difficult to implement in areas with naturally high background values. Although exceeding the safety reference standard values in such areas must not be regarded as necessitating a decontamination of these sites, decontamination should be considered in landuse planning for health and economic reasons. Also, as mentioned, the possible danger presented by metals and semi-metals depends not only on total (mean) chemical concentration but also on the solubility, bioavailability, and mineralogical occurrence of the elements of interest. These aspects should not be underestimated when assessing the environmental or heath risk/impact presented by a site.

\section{CONCLUSION}

Statistical analysis of elemental concentrations of soil and stream sediment samples collected in the vicinity of the Nisa uranium ore deposit (Portugal) has identified two groups of elements: Group I, composed of $\mathrm{U}-\mathrm{Mb}-\mathrm{Nb}$, and Group II, composed of As-Cr-V. The correlations between these elements may be explained in terms of ore deposit paragenesis and mineralization history. Both uranium and arsenic occur in abnormal concentrations as a natural consequence of the geological processes and mineralization that occurred in the area. Reference concentration values applicable to the elements measured in soil and stream sediments in the presence of the natural geochemical anomaly were compared with regulationbased guideline values. The comparisons indicate that the identification and characterization of natural geochemical anomalies must not be neglected either in land-use planning or in decision-making regarding possible decontamination.

\section{ACKNOWLEDGEMENTS}

We thank Dr. António Campos for his advices and help during the fieldwork. This work is a contribution to Project UID/GEO/04035/2013 funded by Fundação para a Ciência e a Tecnologia (FCT), Portugal.

\section{Author contributions}

All authors contributed equally in this article.

\section{REFERENCES}

Albanese, S., B. De Vivo, A. Lima and D. Cicchella. 2007. Geochemical background and baseline values of toxic elements in stream sediments of Campania region (Italy). J. Geochem. Explor. 93(1): 21-34.

Alexakis, D. 2008. Geochemistry of stream sediments as a tool for assessing contamination by arsenic, chromium and other toxic elements: East Attica region. Greece Eur. Water. 21(22): 57-72.

Alves de Campos, A. 2002. Radiological impacts of mineral deposits of uranium: The case study of the Nisa deposit (Nisa - Center of Portugal) (Impactes radiológicos associados a depósitos minerais de urânio: O caso do jazigo de Nisa (Nisa - Portugal Central). MSc Dissertation, Faculty of Science and Technology, University of Coimbra.

Barbosa, S. 2014. Geochemical reference values of portuguese soils - Local and regional anomalies (Situação de referência sobre a geoquímica dos solos portugueses - Casos de anomalias naturais locais e regionais). In: Proceedings of the Workshop "Solos Contaminados: Legislação e Métodos de Diagnóstico e Investigação". Publisher LNEC, Lisboa.

Beckhoff, B. 2006. Handbook of Practical X-ray Fluorescence Analysis, Springer, New York.

Cabral-Pinto, M. M. S., E. A. Ferreira da Silva, M. M. V. Silva and P. A. Dinis. 2014. Estimated background values maps of uranium in Santiago Island topsoil and stream sediments. Proc. Earth Planet. Sci. 8: 23-27.

Charifo, G., A. M. Ferreira, J. A. Almeida and J. P. Prian. 2015. Geochemical and statistical characterization of the phosphate facies of the Farim-Saliquinhé phosphate mineralization (Guinea-Bissau). Resour. Geol. 64(1): 58-75.

Cheng, Q., G. Bonham-Carter, W. Wang, S. Zhang, L. Wenchang and X. Qinglin. 2011. A spatially weighted principal component analysis for multi-element geochemical data for mapping locations of felsic intrusions in the Gejiu mineral district of Yunnan, China. Comput. Geosci. 37(5): 662-669. 
Cunha, P. P., J. Pais and P. Legoinha. 2009. Cenozoic geological evolution of Continental Portugal - aluvial and marine sedimentation in a passive continental margin (Ocidental Iberia) (Evolução geológica de Portugal continental durante o Cenozóico - Sedimentação aluvial e marinha numa margem continental passiva (Ibéria ocidental). In: Proceedings of the "6 ${ }^{\circ}$ Simposio Sobre El Margen Ibérico Atlántico", Oviedo.

Dutch Legislation, V. R. O. 2000. Circular on target values and intervention values for soil remediation. Netherlands Government Gazette, No. 39, Ministry of Housing, Spatial Planning and Environment, Directorate General for Environmental Protection, Department of Soil Protection, The Hague Widerlund A, Shcherbakova; 2000.

Faria, F. L and L. P. Mesquita. 1962. The Nisa-Castelo de Vide uranium mineral deposits (Jazigos de urânio da região de Nisa - Castelo de Vide). Bol. Soc. Geol. Portugal. XIV: 121-150.

Ferreira, N., M. Iglesias, F. Noronha, E. Pereira, A. Ribeiro and L. Ribeiro. 1987. Central Iberian granites and its geodinamics (Granitóides da Zona Centro Ibérica e seu enquadramento geodinâmico). In: Homenaje, A. L., G. Figuerola, (Eds.), Geologia dos Granitóides y Rocas Associadas del Macizo Hespérico, Rueda, Madrid.

Guimarães, T., J. A. Almeida, M. G. Brito, R. Salgueiro, E. Ferreira da Silva, C. Candeias and P. F. Ávila. 2014. Copper concentration in soils and sediments in the Aljustrel mine sorrounding areas (Caracterização de teores em cobre nos solos e sedimentos na envolvente à Mina de Aljustrel). Commun. Geol. 101: 10151018.

IAEA. 2001. Generic Models for Use in Assessing the Impact of Discharges of Radioactive Substances to the Environment. International Atomic Energy Agency Safety Reports Series, $N^{\circ}$ 19, Vienna.

Isaaks, E. H. and R. M. Srivastava. 1989. An Introduction to Applied Geostatistics, Oxford University Press, New York.

Kayzar, T. M., A. C. Villa, M. L. Lobaugh, A. M. Gaffney and R. W. Williams. 2014. Investigating uranium distribution in surface sediments and waters: A case study of contamination from the Juniper Uranium Mine, Stanislaus National Forest, CA. J. Environ. Radioact. 136: 85-97.

McGrath, S. P and K. T. Semple. 2010. Bioavailability of metals and organic contaminants in soils. In: Proceedings of the $19^{\text {th }}$ World Congress of Soil Science, Soil Solutions for a Changing World, Brisbane, Australia, Pp. 20-23.

Ministry of the Environment. 2011. Soil, Ground Water and Sediment Standards for Use. Canadian Legislation. Under Part XV.1 of the Environmental Protection Act.

Moura, A. and J. Velho. 2011. Recursos Geológicos de Portugal. Palimage, Coimbra.

Neiva, A. M. R., I. M. H. Antunes, P. C. S. Carvalho and A. C. T. Santos. 2016. Uranium and arsenic contamination in the former Mondego Sul uranium mine area, central Portugal. J. Geochem. Explor. 162: 1-15.

Neto de Carvalho, C., J. Rodrigues and D. Metodiev. 2009. Geological inheritance inventory of vila velha de rodão. contribution for geopark naturtejo (Inventário do património geológico do concelho de Vila Velha de Rodão: Contributo para a caracterização do geopark Naturtejo da Meseta Meridional). Açafa Online. 2: 1-53.

Neto de Carvalho, C. and J. J. Rodrigues. 2012. Geological and geo-mining heritage of Nisa: territory characterization and its integration on Geopark Naturtejo. Património Geológico e Geomineiro de Nisa: Caracterização do território e sua integração no Geopark Naturtejo. Açafa Online. 5: 91-168.

Portugal, M. F. V. 1971. Portuguese uranium mineral depoists and Au-Ag-Sulphide minereal deposits of North Portugal: guidebook excursion. Directorate-General of Geological and Mining Services, Lisbon. (Jazigos uraníferos portugueses jazigos de Au-Ag-sulfuretos do norte de Portugal: Livro-guia da excursão. Direção-Geral de Minas e Serviços Geológicos, Lisboa.).

Prazeres, C. M. 2011. Geochemical, radiometric and mineralogical charaterization of some Nisa uranium deposit mineralization (Caracterização geoquímica, radiométrica e mineralógica de algumas mineralizações de urânio da região de Nisa) MSc Dissertation, Faculdade de Ciências da Universidade de Lisboa.

Ribeiro, O., C. Teixeira, H. Carvalho, A. Peres and A. P. Fernandes. 1965. Portuguese Geological Map, scale 1:50000 (Carta Geológica de Portugal à escala 1:50000, folha $28 \mathrm{~B}$, Nisa). Serviços de Geologia, Lisboa, Portugal.

Rodriguez-Alvarez, M. J and F. Sanchez. 2000. Modelling of U, Th, $\mathrm{Ra}$ and $137 \mathrm{Cs}$ radionuclides behaviour in rivers. Comparison with field observations. Appl. Math. Model. 25(1): 57.

Roxo, S., J. A. Almeida, F. V. Matias, H. Mata-Lima and S. Barbosa. 2016. The use of sensory perception indicators for improving the characterization and modelling of total petroleum hydrocarbon (TPH) grade in soils. Environ. Monit. Assess. 188(3): 1-19.

Sakan, S. M., D. S. Dordevic and S. S. Trifunovic. 2011. Geochemical and statistical methods in the evaluation of trace elements contamination: An application on canal sediments. Polish J. Environ. Stud. 20(1): 187-199.

Salgueiro, R., H. G. Pereira, E. Ferreira da Silva, J. Matos and, P. H. Ávila. 2007. Principal components Analysis as a tool for identifying contaminated stream sediment samples in the Aljustrel Mining area. In: Proceedings of the Geochemical Iberian Congress and the XV Geochemical Week (In: Actas do VI Congresso Ibérico de Geoquímica e XV Semana da Geoquímica), UTAD, Portugal.,Pp. 266-269.

Siegbahn, K. 1965. Alpha-Beta-and Gamma-Ray Spectroscopy. Elsevier Science Ltd., Amsterdam.

Soares, A., J. Tavora, L. Pinheiro, C. Freitas and J. Almeida. 1993. Predicting probability maps of air pollution concentration: A case study on barreiro/seixal industrial area. In: A. Soares (Ed.), Geostatistics Troia '92, Vol. 2. Kluwer Academic Publishers, Dordrecht, Pp. 625-636.

Solá, A. R. 2007. Petrological and geochemical relations of NEAlentejo Massive Granites (Relações Petrogeoquímicas dos Maciços Graníticos do NE Alentejano). PhD Dissertation, University of Coimbra, Portugal.

Takac, P., T. Szabova, L. Kozakova and M. Benkova. 2009. Heavy metals and their bioavailability from soils in the long-term polluted Central Spis region of SR. Plant Soil Environ. 55: 167-172.

United States Army Corps of Engineers. 2007. Guidelines for Sampling Bed Material, Technical Supplement 13A, Part 654 of National Engineering, Handbook, New England District. Zheleznyak, M., G. Donchyts, V. Hygynyak, A. Marinetz, G. Lyashenko and P. Tkalich. 1997. RIVTOX - One dimensional model for the simulation of the transport of radionuclides in a network of river channels. RODOS Report WG4-TN(97)05, Forschungszentrum Karlsruhe, 2000, p. 48. 